\title{
Synthesis, Characterization, and Electrochemical Behavior of Viologen-Functionalized Poly(Amidoamine) Dendrimers
}

\author{
Mi-Kyung Oh, Sang-Eun Bae, Jung-Hyun Yoon, Mary F. Roberts, ${ }^{\circ}$ Eunhee Cha, and Chi-Woo J. Lee \\ Division of Natural Science, Korea University. Jochiwon. Choongnam 339-700. Korea \\ ${ }^{\dagger}$ Chemistry Deparment, Boston College, Chestmut Hill, MA 02167. USA \\ Received March 6, 2004
}

\begin{abstract}
Amineterminated. ethylenediamine core polyamidoamine starburst dendrimers of generation 2 (G2), generation $+(\mathrm{G}+)$ and generation $6(\mathrm{G} 6)$ have been successfully surface-modified via an amide coupling reaction with 4-ethyl 4'-(3-propionic) bipy'ridinium cation and the electrochemical behavior of the resulting dendrimers were investigated in aqueous potassium chloride electrolyte solutions. The 1-[3-(dimethylamino)propyl]-3ethyy lcarbodiimide hydrochloride/N-hy'droxysuccinimide-mediated reaction resulted in $25-39 \%$ end-group functionalization. The water-soluble 4-ethyl. 4'-(3-propylamide) bipy ridinium dibromide dendrimers (G2$\mathrm{V} 2+, \mathrm{G} 4-\mathrm{V} 2+$ and G6-V2+) were characterized by ${ }^{1} \mathrm{H}$ NMR and UV-Vis spectroscopic methods. The crclic voltammetric and chronoamperometric experiments were performed to determine the diffusion coefficient and the number of electrons transferred in the process of the first reduction of the viologen-functionalized dendrimers. Adsorption of viologen-functionalized dendrimers at electrode surface was evidenced in the voltammograms. Experimentally determined diffusion coefficients were in good agreement with the values expected from the Stokes-Einstein relation. while the number of electrons transferred concurred with the extent of functionalization determined by ${ }^{~} \mathrm{H} \mathrm{NMR}$ and UV-Vis spectra.
\end{abstract}

Key Words : Viologen. Dendrimer, Electrochemistry

\section{Introduction}

The synthesis and characterization of dendrimers have been of recent interest due to their well-defined threedimensional geonetry, generational variety. ease of functionalization, and potential for the practical nano particle applications ${ }^{1-6}$ Monolayers or multilayers of dendrimers can be formed by self-assembly at or through covalent-attachment to the substrate or supporting organic thin film, making them ideal for use in studies of self-assembly (SAMs). ${ }^{7}$ liquid crystalline devices, ${ }^{8}$ and conductive film technology. Dendritic macromolecules possessing functionalities capable of absorbing and emitting light have been used as molecular light harvesters, ${ }^{16}$ and solvatochromic probes. ${ }^{11}$ The recent reports described the application of an electrostatically bound DNA-dendrimer complexes for use as gene transfer vectors through cell membranes. ${ }^{1.13}$ Dendrimers having redox-active centers including coordinated metal sites are of particular interest because they have potential applications in the field of chemical sensors, ${ }^{14}$ multielectron redox catalysts. ${ }^{15}$ and molecular electronic devices. ${ }^{16.17}$ In terms of employing dendrimers as electrochemical probes, the preparation of electro-active dendrimers functionalized with redox-active species such as ferrocene, ${ }^{18.15}$ anthraquinone, ${ }^{31}$ and ruthenium(II) complexes ${ }^{21.2}$ have been described. In this work. we wish to report synthesis and electrochemistry of three different generations of poly (amidoamine) (PAMAM) dendrimers funtionalized with a t-ethyl. +'-propylamidebi-

\footnotetext{
Author to whom correspondence should be addressed: M. $-\mathrm{K}$. Oh (viologenakorea.ac.kr), C.-W. J. Lee (cwleeakorea.ac.kr)
}

pyridinium (viologen) moiety (G2-V2+. G4-V2+ (Figure l), and $\mathrm{G} 6-\mathrm{V} 2+$ ). which can be utilized in multi-electron redox catalysts. electrocataly sis, photochemistry and photoelectrochemistry and electrochromic devices ${ }^{23-28}$ The water-soluble viologenated-dendrimers were imvestigated by ${ }^{1} \mathrm{H}$ NMR, UV-Visible spectroscopy. and electrochemistry. Cyclic voltammetry and chronoamperometry were employed to obtain the number of electrons transferred (n) during the first redox process and the diffusion coefficient (D) of the three size-differentiated viologen $(2+)$ macromolecules.

\section{Experimental Section}

Materials and Apparatus. Amine terminated generation 2, 4. and 6 STARBURST ${ }^{\text {TM }}$ PAMAM dendrimers were supplied by Dendritech. Inc. (Midland. MI). N-hydroxysuccinimide (NHS) and 1-[3-(Dimethylamino)propyl]-3-etlyylcarbodiimide hydrochloride (EDC) were purchased from Aldrich Triethanolamine, bromopropionic acid. bromoethane, $\mathrm{K}_{2} \mathrm{SO}_{4}$ and $\mathrm{KCl}$ salts were purchased from Aldrich and used as received. $\mathrm{Ru}\left(\mathrm{NH}_{3}\right)_{6} \mathrm{Cl}_{3}$ used as standard redox reagent in electrochemical measurement, was purchased from Strem Chemicals. Solutions were prepared from deionized water (Ultrapure Milli-Q water, Millipore Corp.).

${ }^{1} \mathrm{H}$ NMR and UV-Vis measurements. ${ }^{\mathrm{H}} \mathrm{H}$ NMR spectra were obtained in $\mathrm{D}_{2} \mathrm{O}(99.9 \%$, Cambridge Isotope Laboratory. Andover, MA) on a Varian $200(200 \mathrm{MHz})$ spectrometer. UV-Visible spectra were acquired using a Hewlett-Packard Model 8453 UV-Vis spectrometer.

Electrochemistry. Electrochemical experiments were carried out using a BAS $100 \mathrm{~A}$ electrochemical analyzer 


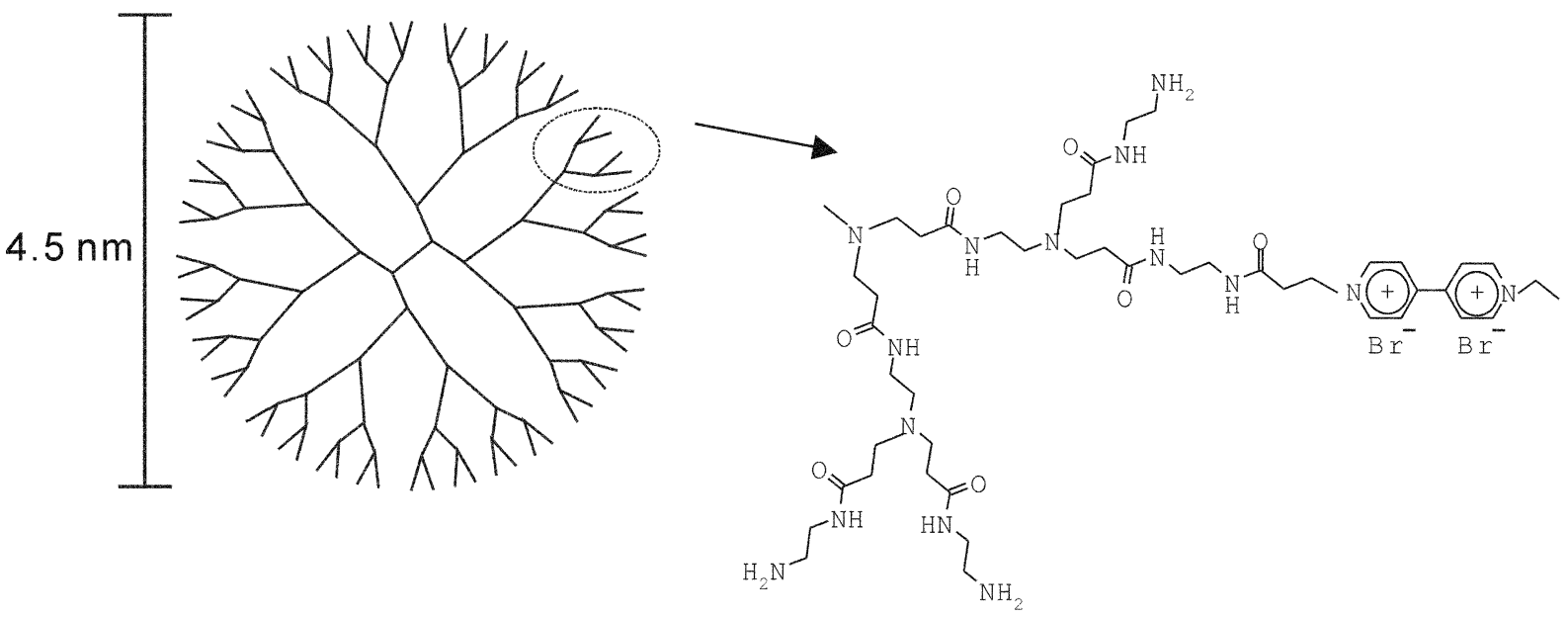

Figure 1. Tiwo demensional schematic structure of viologen-modified generation 4 PAMAM dendrimer (G4-V2 $)$.

(Bioanalytical Systems, West l afayett, Inc.), a Pine Instrument AFRDF:4 bipotentiostat (Grove City, PA) and Kipp and 7onen $X Y Y^{\prime}$ chart recorder (Bohemia, NY), Glassy carbon electrode (GCF, radius: $1.5 \mathrm{~mm}$, BAS), Pt electrode (radius: $1.0 \mathrm{~mm}, \mathrm{BAS}$ ), and $\mathrm{Pt}$ microelectrode (radius: $5 \mu \mathrm{m}, \mathrm{BAS}$ ) were used as working electrodes. $\mathrm{Ag} \mid \mathrm{AgCl}(3 \mathrm{M} \mathrm{NaCl}$. $\mathrm{BAS}$ ) and a Pt-gauze were used as the reference and counter electrodes. Prior to electrochemical experiments, the working electrodes were polished with $1 \mu \mathrm{m}$ and $0.1 \mu \mathrm{m}-\mathrm{Al}_{2} \mathrm{O}_{3}$ on a polishing cloth (Buehler [ td., [ ake Bluff, I].) successively. Following the final polishing step, the electrodes were rinsed thoroughly and sonicated with deionized water and ethanol. All experiments were carried out at $22=2{ }^{\circ} \mathrm{C}$ in deoxygenated aqueous solutions.

Synthesis. The viologen precursor was prepared from 4 , 4'-bipyridine with bromoetlane and 3-bromopropionic acid in benzene. ${ }^{29}$ Dendrimers were modified with the viologens according to the $\mathrm{EDC}$ N NHS coupling procedure by Vijay, et $a{ }^{30}$ Scheme 1 outlines the synthetic sequence. An aqueous solution ( $5 \mathrm{ml}$ ) of NHS (150 mg) and viologen precursor (400 $\mathrm{mg}$ ) was stirred for $1 \mathrm{~h}$ at $0^{\circ} \mathrm{C}$. ГDC (500 mg) was added, and the mixture was stirred for $10 \mathrm{~min}$ at $0^{\circ} \mathrm{C}$, and then at room temperature for an additional $10 \mathrm{~min}$. Next. PAMAM dendrimers dissolved in $4 \mathrm{ml}$, buffer solution $(0.1$ $\mathrm{M}$ ТГ:A adjusted to $\mathrm{pH} 8$ with $\mathrm{KOH}$ ) were combined with the activated viologen precursor. The amount of dendrimer used was adjusted, according to dendrimer generation, to establish a 1:2:2:10 molar ratio among the dendrimer terminal amines, viologen precursor, NHS, and EDC, respectively. The final solution $\mathrm{pH}$ was adjusted to 8.0 by adding dilute $\mathrm{KOH}$, which was then stirred overnight at room temperature and then purified using dialysis for one<smiles>CCCCCCCCC(=O)Br</smiles><smiles></smiles>

(A) $\mathrm{Br}^{-}$

(A) +<smiles>C[13C](Br)CCC(=O)O</smiles><smiles></smiles>

(B) +<smiles>O=C1CCC(=O)N1O</smiles><smiles>C=C1CCC(=O)N1C</smiles><smiles>COCC(=O)OC</smiles><smiles>CNCCCBr</smiles><smiles></smiles>

(C) + Gn-PAMAM dendrimers

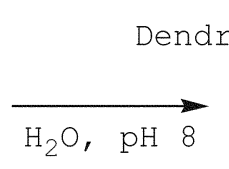

endrimers<smiles>OCCS</smiles><smiles></smiles>

Scheme 1. The synthetic sequence of viologen-lunctionalized PAMAM dendrimers. 


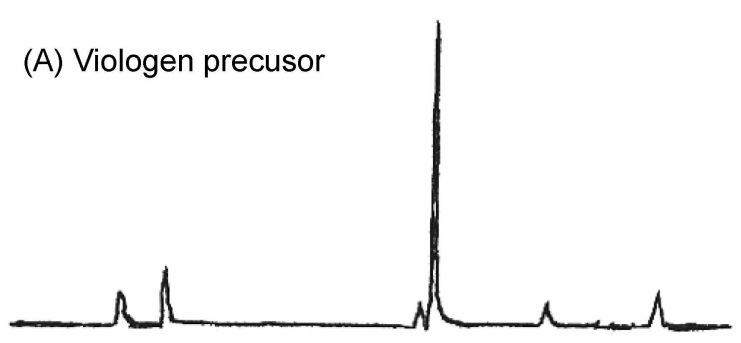

(B) G4-V2+

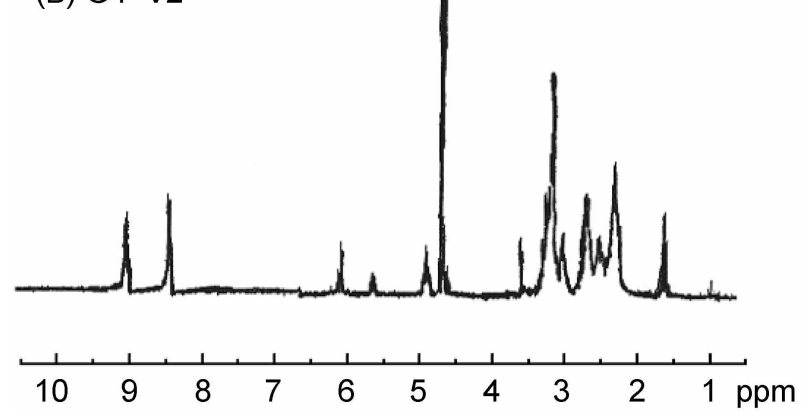

Figure 2. 'II VMR spectra of ( $A$ ) viologen precursor and (B) G2$\mathrm{V} 2+$.

day, A tibrous blue-green powder was formed after $24 \mathrm{~h}$ lyophilization (Freezone 6, L abconco, Kansas City, MO).

\section{Results and Discussion}

The primary objective of this study was to examine the structural and electrochemical properties of the viologenated-dendrimers (VDs). Figure 2 shows ' $\mathrm{H}$ NMR spectra of the viologen precursor $(A)$ and $\mathrm{G} 2-\mathrm{V} 2-(\mathrm{B})$. New signals between 2.1-3.5 ppm (Dendrimer methylen protons ${ }^{31}$ ) that were absent from the spectra of viologen precursor were shown at the G4-V2- spectrum. The NMR spectra of G4V2+ and G6-V2+ also showed the peaks near the same chemical shifts. The 4,4'-bipyridinium unit signals of the viologen precursor and the VDs attached to periphery of dendrimers exhibited a similar shift around $8.4 \mathrm{ppm}$ and 9.0 ppm. ${ }^{i 2}$ The number of viologens per dendrimer was established from the ratio of the integrated viologen methylene hydrogens (at $1.7 \mathrm{ppm}$ ) to the dendrimer methylene hydrogens (at $3.3 \mathrm{ppm}$ ), after normalization with respect to the number of hydrogens per molecule represented within the integral region.

Figure 3 shows UV-Vis spectra of identical molar concentration $2.4 \mu \mathrm{M}$ of viologen precursor, G2-V2+, and G4-V2+, and $0.8 \mu \mathrm{M}$ of $\mathrm{G} 6-\mathrm{V}_{2}-$. The spectra were obtained from the experiments performed after a calculated molar concentration of modified viologen onto dendrimer for using molar extinction coefficient $\left(21000 \mathrm{M}^{-1} \mathrm{~cm}^{-1}\right.$ at $\left.259 \mathrm{~nm}\right)$ of viologen precursor $\left(\mathrm{V}^{2+}\right) .{ }^{3.3}$ lhe absorption was attributed to viologen $\pi-\pi^{*}$ transitions and provides a basis for determining the degree of end group functionalized of viologenated dendrimer and gravimetric analysis. The increase in absorption is due to an increasing number of viologen units attached to the periphery of dendrimers with increasing

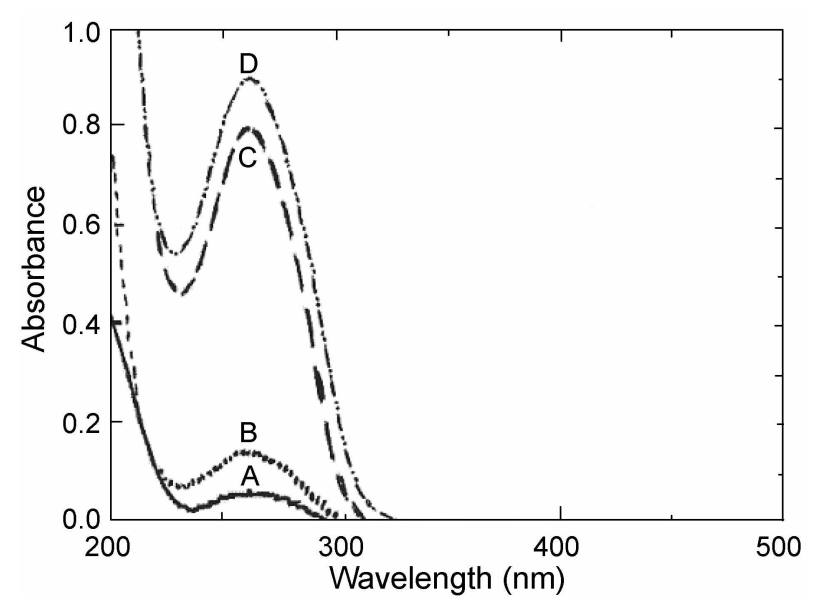

Figure 3. LV V-Vis spectra of $2.4 \mathrm{mM}(A)$ viologen precursor. (B) $\mathrm{G} 2-\mathrm{V} 2+$ and (C) $(44-\mathrm{V} 2-$, and $0.8 \mathrm{mM}$ (D) $(\mathrm{i} 6-\mathrm{V} 2+$ in axplucous solutions.

Table 1. 'The number of viologens on the three dendrimers surlaces obtained by '] -NMR and UV-Vis sputroscopy

\begin{tabular}{|c|c|c|c|c|}
\hline \multirow{2}{*}{ Gn } & \multirow{2}{*}{$\begin{array}{c}\text { Diamstrs } \\
(\Lambda)^{k s}\end{array}$} & \multirow{2}{*}{$\begin{array}{l}\text { Number of } \\
\text { surface groups } \\
\text { (g/mol })^{t}\end{array}$} & \multicolumn{2}{|c|}{$\begin{array}{l}\text { Number of viologens } \\
\text { on dendrimer surface }\end{array}$} \\
\hline & & & 'II-NMR & UV-Vis \\
\hline $\mathrm{G} 2$ & 29 & $\begin{array}{c}16 \\
(3.256)\end{array}$ & $\begin{array}{c}4.3 \\
(27 \%)\end{array}$ & $\begin{array}{c}4.8 \\
(30 \%)\end{array}$ \\
\hline G4 & 45 & $\begin{array}{c}64 \\
(14.215)\end{array}$ & $\begin{array}{l}21.8 \\
\left(34^{10} \%\right)\end{array}$ & $\begin{array}{c}25,5 \\
(39 \%)\end{array}$ \\
\hline (j6 & 67 & $\begin{array}{c}256 \\
(58.048)\end{array}$ & $\begin{array}{c}63,1 \\
(25 \%)\end{array}$ & $\begin{array}{c}68.4 \\
(27 \%)\end{array}$ \\
\hline
\end{tabular}

"Relerence: Technology Review by Dendritech, Inc. 1995.

generation. 'H NMR and UV-Vis spectra could be used to determine the molecular weights and molar concentrations independently. These results indicated that $25-39 \%$ viologen functionalization of the dendrimers periphery was accomplished for the dendrimers (G2-V2+, G4-V2--, and G6$\mathrm{V} 2+)$. Incomplete functionalization is likely a result of repulsion among positive charges of 4.4'-bipyridinium, and the mild reaction conditions employed. The degree of functionalization determined by both ${ }^{1} \mathrm{H} N \mathrm{NMR}$ and UV-Vis was summarized in lable $\mathrm{l}$ and the results from the two independent methods are in good agreement.

Figure 4 shows cyclic voltammograms of $0.040 \mathrm{mM} \mathrm{G2-}$ $\mathrm{V} 2+, \mathrm{G} 4-\mathrm{V} 2+$, and $\mathrm{G} 6-\mathrm{V} 2+$ in aqueous solutions at the scan rate of $0.1 \mathrm{~V} / \mathrm{s}(\mathrm{w} . \mathrm{Ag} \mid \mathrm{AgCl}(3 \mathrm{M} \mathrm{NaCl}))$ by using the glassy carbon electrode. $\mathrm{G} 2-\mathrm{V} 2+$ shows a near diffusion shape. On the other hand two peaks were observed on the reverse scan of voltammograms $\mathrm{G} 4-\mathrm{V} 2+$. The broad peak results from diffusion of solubilized $\mathrm{G} 4-\mathrm{V}-$, while the sharp peak represents the oxidation of the reduced radical cations that have adsorbed at the electrode surface. G6-V2+ has a sharp reverse peak, which indicates stronger adsorption of the reduced VDs at the electrode surface with the change in the oxidation state of the viologen units on the dendritic surface. The facts that methyl viologen $(2+/-)$ does not adsorb at the electrode surface in the similar conditions. ${ }^{25}$ 


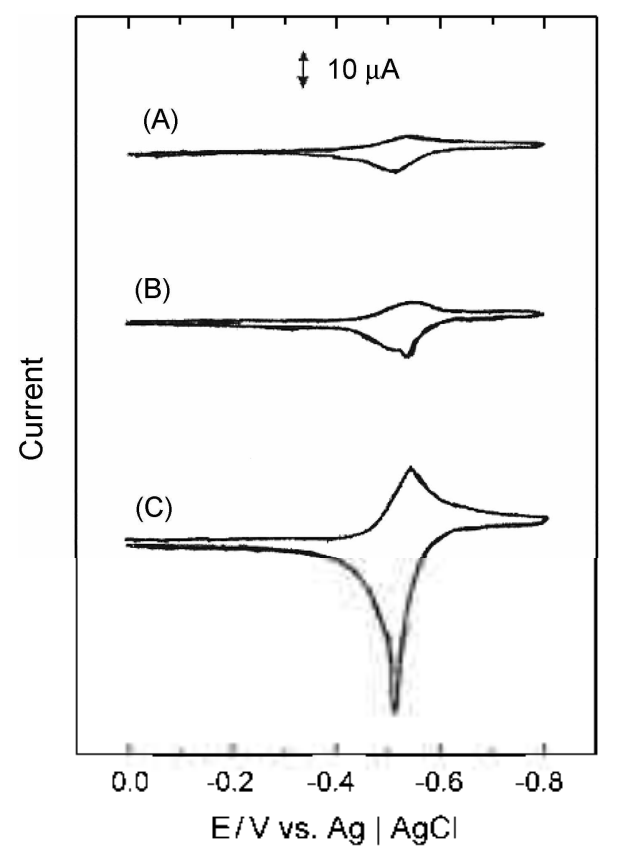

Figure 4. Cyclic voltammograms of $40 \mu \mathrm{M}$ (A) (i2-V2+. (B) G4$\mathrm{V} 2+$. and (C) $\mathrm{G} 6-\mathrm{V} 2-$ at a glassy carbon electrode (radius: 1.5 mm). Supporting electrolyte: $0.1 \mathrm{M} \mathrm{KCl}$ adueous solution. Scan rate: $100 \mathrm{mV} / \mathrm{s}$.

that G4-V+ does, and that the extent of adsorption becomes stronger as the size of dendrimer increases reflects that the adsorption of the reduced VDs is promoted by the dendrimer, to which the viologen unit is attached. Figure 5 shows the scan rate dependence of the cyclic voltammetric response (A), the corresponding Randles-Sevcik equation plot for the diffusion process using $A(B){ }^{3.1}$ and the Cottrell plot of $\mathrm{I}(\mathrm{t}) v \mathrm{~s}^{-t^{-1: 2}}$ for the $\mathrm{G} 2-\mathrm{V} 2-$ at a $\mathrm{Pt}$ planar electrode (C). In the chronoamperometric experiment, the potential was stepped from 0 to $-0.6 \mathrm{~V}$ and held for $1000 \mathrm{~ms}$ to obtain a plot of $\mathrm{l}(\mathrm{t})$ is. $t^{-1: 2}$. Similar cyclic voltammograms and chronoamperograms were observed for G4-V2- and G6$\mathrm{V} 2+$. The steady-state voltammograms of $\mathrm{G} 2-\mathrm{V} 2-$, G4 $-\mathrm{V} 2+$, and $\mathrm{G} 6-\mathrm{V} 2+$ were obtained at the $\mathrm{l}^{\mathrm{P}} \mathrm{m}$ microdisk electrode in $0.1 \mathrm{M} \mathrm{KCl}$ aqueous solution (Figure 6). As with the cyclic voltammograms at the Pt planar electrode, G4-V2+ and G6$\mathrm{V} 2+$ have shown an adsorption peak during the reverse scan. The peak intensity increased with increasing generation of dendrimers as was observed at macroeledtrode and it did also with increasing the $\mathrm{pH}$ as is shown in Figure 7 . The solubility of the reduced form increases at low $\mathrm{pH}$ because the terminal amine group of dendrimers is protonated. . $^{3.36}$ Additionally, the formal potentials $\left(\mathbb{E}^{0}\right)$ of three viologenfunctionalized dendrimers obtained from curves of the steady-state current are virtually identical at -0.55 (G2-V2+), $-0.54(\mathrm{G} 4-\mathrm{V} 2+)$ and $-0.54 \mathrm{~V}(\mathrm{G} 6-\mathrm{V} 2-) \mathrm{ws} . \mathrm{Ag} \mid \mathrm{AgCl}(3 \mathrm{M}$ $\mathrm{NaCl}$ ). The similar potential values mean that all of the viologen moieties attached to the periphery of the dendrimers act independently, and the number of dendrimers generation does not affect the redox property of viologen functional group. The electron transfer number ( $n$ ) and diffusion coefficient (D) of the three VDs can be determined
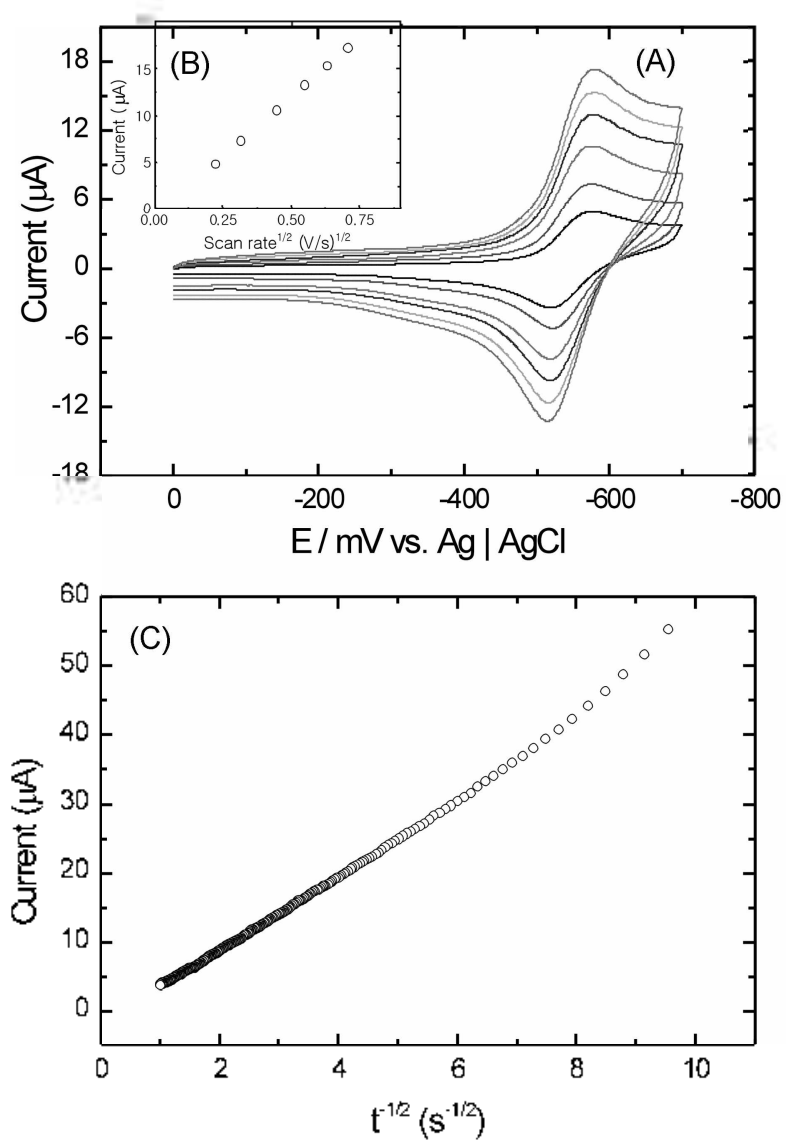

Figure 5. (A) Cyclic voltammograms. Scan rate: 0.05 .0 .1 . 0.2. 0.3 . $0.4 .0 .5 \mathrm{~V} / \mathrm{s}$. (B) plot of peak current $(\mu \mathrm{A}) w \mathrm{~s}$. scan rate $(\mathrm{V} / \mathrm{s})^{\prime 2}$. and (C) plot of lii) vs. $f^{-1: 2}$ recorded under potential $-600 \mathrm{mV}$ of 0.67 m.M (j2-V2 I a a P1 planar electrode (radius: $1.0 \mathrm{~mm}$ ) in $0.1 \mathrm{M}$ $\mathrm{KCl}$ aqueous solution.

from the cyclic voltammograms at a Pt microelectrode and the chronoamperogram ${ }^{37}$ at a Pt macroelectrode. The values $n$ and $D$ of VDs can be calculated from ratios of the radial and linear diffusion-controlled currents for the unknown and standard reactants. ${ }^{78} \mathrm{Ru}\left(\mathrm{NH}_{3}\right)_{i}{ }^{3+}$ was chosen as the electrochemical standard and the diffusion coefficient of $\mathrm{Ru}\left(\mathrm{NH}_{3}\right)_{6}{ }^{3-}$ was determined to be $5.6 \times 10^{-6} \mathrm{~cm}^{2} / \mathrm{s}$ by using steady-state and linear diffusion-controlled currents. ${ }^{39}$ Equation 1 describes the steady-state current $\left(I_{c o}\right.$ is unknown reactant current. $I_{\infty}$, is standard reactant current) at a microdisk electrode under conditions of radial diffusion.

$$
i_{\infty}=i_{\infty s}=4 r n F^{*} D
$$

Ilere, $n$ is the number of electrons transferred. $F$ is the Faraday constant, $D$ is the diffusion coefficient, $C^{*}$ is the concentration of electroactive species in the solution, $r$ is the radius of the microelectrode. In order to obtain the results for VDs reactions, the standard electrode reaction was performed at the same P1 microelectrode. The ratio of the steadystate currents for the VDs and standards reactant is given by equation 2 .

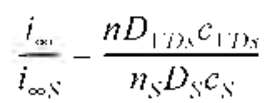



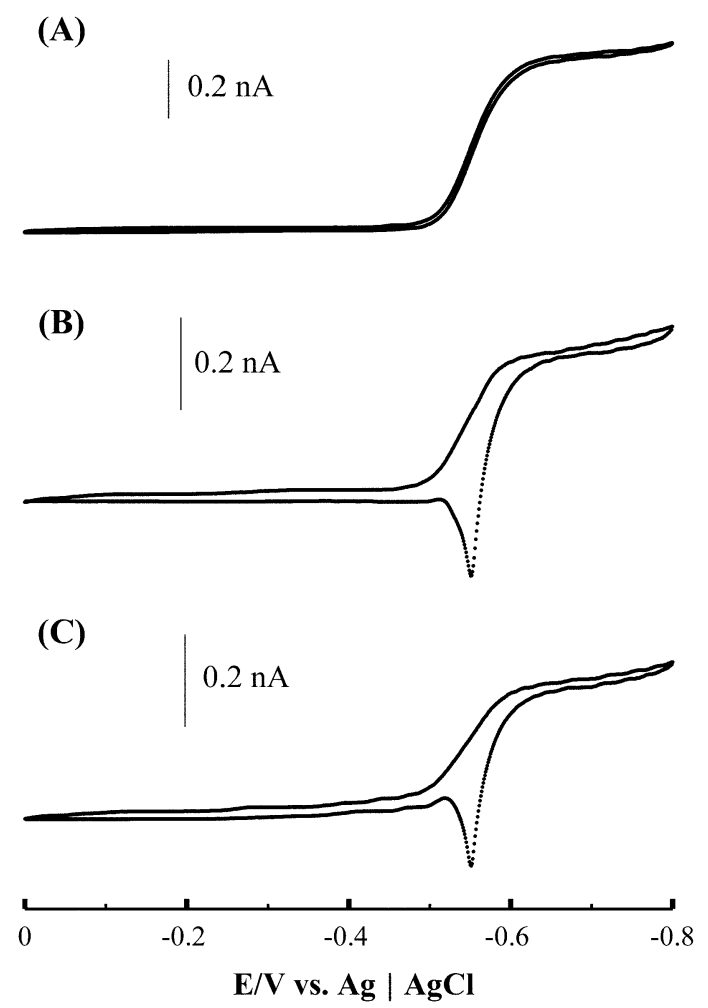

Figure 6. Cyclic voltammogams at $10 \mu \mathrm{m}$ diameter disk $\mathrm{Pt}$ microelectrode in $0.1 \mathrm{M}$ acpueous $\mathrm{KCl}$ solution (pl 7.4 ) containing (A) $0.67 \mathrm{m.M} \mathrm{G2-V2+.} \mathrm{(B)} 0.12 \mathrm{mM} \mathrm{G} 4-\mathrm{V} 2+$ and (C) $0.049 \mathrm{mM}$ G6-V2+. Scan ratc: $10 \mathrm{mV} / \mathrm{s}$.

Where $n_{S}$ is the number of electrons transferred, $D_{S}$ and $C_{S}$ are the diffusion coefficient and concentration of standard reaction, respectively. linear diffusion-controlled current at a Pt planar electrode of area $\mathrm{A}$ is given by the Cottrell equation ( :quation 3), Using equation 3, the ratio of the slopes of $I$ vs. $t^{-1: 2}$ for the VDS $\left(S_{V \text { VS }}\right)$ and for standard reactant ( $\mathrm{S}_{\mathrm{s}}$ ) at the same planar electrode yields (Equation 4 )

$$
\begin{aligned}
& i-\frac{n F A D^{1 / 2} c}{\pi^{1 / 2} t^{1 / 2}} \\
& \frac{S}{S_{S}}-\frac{n D_{\Gamma \eta)_{S}}^{1 / 2} c_{1)_{S}}}{n_{S} D_{S}^{1 / 2} c_{S}}
\end{aligned}
$$

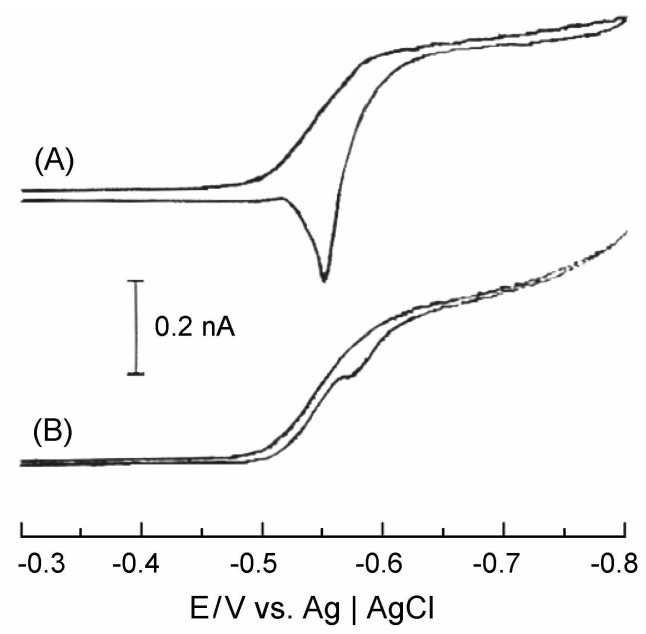

Figure 7. Cyclic voltammograms for $0.12 \mathrm{mM} \mathrm{G4-V2+(A)} \mathrm{in} 0.1$ $\mathrm{M}$ aqueous $\mathrm{KCl}$ solution $\left(\mathrm{p} \mathrm{H}\right.$ 7.4). and $(\mathrm{B})$ in $0.1 \mathrm{M} \mathrm{KH}_{2} \mathrm{PO}_{4}$ buffer solution (pll 6.3) at $10 \mu \mathrm{m}$ diameter disk Pt microelectrode. Scan rate: $10 \mathrm{mV} / \mathrm{s}$.

The electron transfer numbers for the unknown may be calculated by combining equations 2 and 4 . That is

$$
\frac{n}{n_{S}}=\frac{S^{2} i_{\infty S} c_{S}}{S_{S}^{2} i_{\infty} c_{V D S}}
$$

Diffusion coefficient can also be obtained separately by equations 2 and 4 . The expression is

$$
\frac{D_{13 m}}{D_{S}}-\frac{i_{\infty}^{2}, S_{S}^{2}}{i_{s ; \zeta}^{2} S^{2}}
$$

The results of the electrochemical experiments are summarized in Table 2 together with the diffusion coefficients expected from the Stokes-Einstein equation. The diffusion coefficients determined from the voltammetric experiments, which decrease with increasing the viologen-modified dendrimer generation or with increasing the number of viologen units on the dendrimer periphery, are within the range expected from the Stokes-Einstein equation. The number of electrons involved in the first reduction of the dendrimer viologens is

\begin{tabular}{|c|c|c|c|c|c|c|c|c|}
\hline $\begin{array}{l}\text { Compound } \\
\text { (concentration) }\end{array}$ & $\begin{array}{l}\text { Slope } \\
\times 10^{-0<t}\end{array}$ & $\begin{array}{l}\mathrm{i}_{\mathrm{cks}} \\
/ 11 \mathrm{~A}^{b}\end{array}$ & $\begin{array}{c}D_{1} \mathrm{r}^{\prime}(\mathrm{d} . \mathrm{c}) \\
\times 10^{-7} \mathrm{~cm}^{2} / \mathrm{s}\end{array}$ & $\begin{array}{c}\mathrm{D}_{\mathrm{cal}}{ }^{\prime} \\
\times 10^{-7} \mathrm{~cm}^{2} i \mathrm{~s}\end{array}$ & ]$_{b ; a l}$ & $\begin{array}{l}-E_{t p} \\
\left(V r^{r}\right.\end{array}$ & $\begin{array}{l}-E_{a p} \\
(V)^{\prime}\end{array}$ & $\begin{array}{c}-\mathrm{E}_{(\mathrm{cp}-\mathrm{ap}): 2} \\
(\mathrm{~V})^{2}\end{array}$ \\
\hline $\mathrm{Ru}\left(\mathrm{NI}_{3}\right)_{6}{ }^{3-}(5 \mathrm{mM})^{4}$ & 20 & 5.4 & & 56 & 1 & 0.25 & 0.17 & 0.21 \\
\hline$(\mathrm{j} 2-\mathrm{V} 2+(0.67 \mathrm{mM})$ & 5.4 & 0.61 & $15(9.3 .6 .7)$ & 9.8 & 4.8 & 0.58 & 0.52 & 0.55 \\
\hline$\left(34-V_{2}+(0.12 \mathrm{mM})\right.$ & 3.5 & 0.3 & $9.7(6.9 .5 .3)$ & 5.6 & 23 & 0.56 & 0.52 & 0.54 \\
\hline$(36-\mathrm{V} 2+(0.049 \mathrm{mM})$ & 3.4 & 0.25 & $6.6(5.2 .4 .2)$ & 4.1 & 63.7 & 0.56 & 0.52 & 0.54 \\
\hline
\end{tabular}
in excellent agreement with those determined by ' $\mathrm{H}-\mathrm{NMR}$ and UV-vis spectroscopic methods.

Table 2, lixperimental and ealculated results for the reductions ol G2-V2+, G4-V2t, and Gi6-V2 - in 0.1 M KCl aqueous solution

"The slopes of plot 1 \&.s.t:2 trom chronoamperometry on the Pt macroclectrode (diameter $=1.0 \mathrm{~mm}$ ). Steady-state currents trom Pt microclectrode (diameter $=10 \mu \mathrm{m})$. 'Theoretical diffusion coefficients of three non-modified dendrimers were calculated by Stokes-Finstein equation: (D) is a diflusivity of a solute molecule, $r$ is the radius of the solute molecule. $\eta$ is the viscosity of the solvent, and $V$ is Nogadro's number)

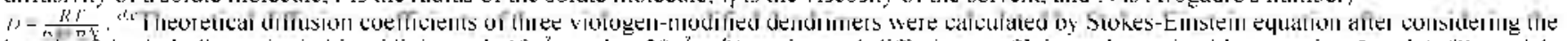
jength of 4-ethyl. 4'-propionic bipyridinium (d: $10 \AA$, and e: $20 \AA$ ). 'Fxperimental diffusion cocfticients determined by equation 5 and 6 . from cyclic voltammogram on the Pt macroelectrode. 


\section{Conclusions}

The preparation, characterization and electrochemical behavior of viologen-functionalized second. fourth. and sixth generation PAMAM dendrimers have been described. The numbers of electroactive units determined independently by ${ }^{1} \mathrm{H}-\mathrm{NMR}$ and UV-vis spectroscopies were in good agreement. The present synthetic conditions led to the 25-39 $\%$ end-group functionalization. The electron transfer number and the diffision coefficient of the three dendrimers prepared were determined by cyclic voltammetry and chronoamperometry in aqueous solutions. The diffision coefficient magnitudes that were obtained from electrochenucal methods decreased with increasing dendrinier generation and were in agreement with the values calculated with the StokesEinstein equation. Electroreduced forms of G4-V+ and G6$\mathrm{V}+$ showed strong adsorption on the electrode surfaces. Additionally, the redox potentials for the first reduction of three viologen-functionalized dendrimers had similar values and all of viologen moieties attached to the periphery of the dendrimer acted independently. Thus these viologen-modified dendrinters may be proved to be useful as molecular electronic devices, electrochromic devices and multielectron redox catalysts.

Acknowledgements. M.-K. Oh was a Postdoctoral Fellow of Korea Science and Engineering Foundation, and this work was supported by Korea Research Foundation (KRF-2002$070-\mathrm{C} 00050$ ) and National Science Foundation (CHE9818302).

\section{References}

1. Storrier. G. D; Takada, K: Abruĩa. H. D. Langmiir 1999, I5. 872 .

2. Tomalia. A. D. Sci. Am. 1995. 62 .

3. Newkome. G. R.: Narayanan. V. V.: Godinez. L. A.: Cordero. E. P.: Echegoven. L. M facrontolecules 1999.32.6782.

4. Dandliker. P. I.: Diederich, F.: Gross. M.: Knobler C. B.: Louati, A.: Sanford. E. M. Angew: Chem. Int Ed Engl. 1994. 33. 1739

5. Achar. S.: Immoos. C. E.: Hill. M. G.: Catalano. V. J. Ifrorg. Chem. 1997.36.2314.

6. Pittelkow. M.: Moth-Poulsen. K.: Boas. U.: Christensen. J. B. Langmiti 2003. 19.7682.

7. (a) Tsukruk; V. V.: Rinderspacher. F.: Bliznyluk, V. N. Langmai 1997, 13, 2171. (b) Emmrich. E: Franzha, S.: Schmid. G.: Majoral. J.-P. Namo Lett. 2002. 1239.

8. Baars. M. W. P. L.: Söntiens. S. H. M.: Fischer. H. M.: Peerlings. H. W. I.: Meijer. E. W. Chem. Em J. 1998, +1. 2456.

9. Miller L. L. Duan. R. G.: Tully. D. C.: Tomalia. D. A. $J$. Am Chem. Soc. 1997. 119. 1005

10. Stewart G. M.: Fox M. A. J. Am. Chem. Soc. $1996,118,4354$
11. Hawker. C. T.: Wooley: K. L.: Frechet. J. M. J. J. Am. Chem. Soc 1993. 115.4375.

12. (a) Lee, J.H.: Lim, Y.-B.; Choi. J.-S.; Choi. M.-U.: Yang. C.-H. Park, J.-S. Bull. Korean Chem. Soc. 2003, 24. 1637. (b) Kim. T.-I.; Jang. H.-S.: Joo. D.-K.: Choi. J.-S.: Park, J.-S. Bull Korew Chent. Soc. 2003. 2f. 123.

13. Ottaqiani. M. F.: Sacchi. B.: Turro. N. T.: Chent. W.: Jochusch. S: Tomalia. D. A Macronolectues 1999. 32. 2275

14. Valério, C.; Fillaut, J. L: Ruiz, J.; Guittard, J:; Blais, J. C.; Astrue D. J. An Chent Soc. 1997, 119.2588.

15. Fillaut, J. L.: Linares. J': Astruc, D. Angew. Chem. Iht. Ed. Engl. 1994. 33. 2460

16. Gorman1. C. B.: Parkhurst. B. L.: Su. W. Y.: Chen. K. Y. d. Am. Chem. Soc. 1997. 119. 1141

17. Cardona C. M.: Kaifer. A. E. J. Am. Chem. Soc. 1998. 120, 4023.

18. Cuadrado. I: Moran. M.; Casado, C. M: Alonso. B : Lobete. F.: Garcia. B.: Ibisate. M.: Losada, J. Onganonetallics 1996. 15. 5278.

19. Takada. K.: Diaz. D. T.: A bruña. H. D.: Cuadrado. I.: Casado. C.: Alonso. B.: Moran. M.: Losada. I. J. Am. Chem. Soc. 1997. 119. 10763

20. Newkome, G. R.: Narayanan, V. V.: Echegoven. L.: Cordero. P. Luftmann. H. Hachonolectles 1997,30.5187.

21. Takada. K.: Storrier. G. D.: Morán. M.: Abrutiaa. H. D. Langumuir 1999. 15.7333

22. Vögtle. F.: Plevoets. M.: Nieger. M.: Azzellini. G. C.: Credi. A.: Cola. L. D.: Marchis. V. D.: Venturi, M.: Balzani. V. J. Ant Chen. Soc. $1999,121,6290$.

23. Kiwi. J.: Grätzel. M. J. Ant Chem. Soc. 1979. 101. 7214.

24. Andrieux. C. P.: Hapiot. P.: Savéant. T. M. J. Electroanal. Chem. 1985. 89.12].

25. (a) Oh. M.-K.: Okajima. T.: Kitamula. F.: Lee. C.-W.: Tokuda. K.: Ohsaka. T. Chem. Lett. 1997. 67. (b) Lee, C.-W.: Oh. M.K. Bull. Korean Chent Soc. 1994. 15. 339. (c) Lee. C.W. Oh, M.K. Jang. J.-M. Lamgnthir 1993. 9.1934.

26. Youn1g. R. C.: Meyer. T. J.: Whitten. D. G. I. Am. Chem. Soc 1975.97 .4781

27. Ward. M. D.: White. T. R.: Bard. A. J. J. Am. Chem. Soc 1983 105.27.

28. Bookbinder. K.: Wrighton, M. S. J. Electrochen. Soc. 1983, 130. 1080 .

29. Gomez. M.: Li. T.: Kaifer. A. E. Langmuir 1991. 7. 1797.

30. Sehgal. D.: Vijay. I. K. Anal. Biochem. 1994. 218.87.

31. Yoon. H.-C.: Hong. M.-Y.: Kim. H.-S. Anal Chem 2000. 72. 4420.

32. Templeton, A. C.: Cliffel, D. E.: Murry, R. W. J. An. Chem. Soc 1999. 121,7081.

33. Watanabe. T: Honda. K. J. Phus. Chem. 1982.86. 2617

34. Bard. J. A.: Faulkner. L. R. Electrochenical Methods. $2^{\text {nd }}$ Ed.: John Wiley \& Sons. Ine.: New York. 2001.

35. Smith. T. W: Kuder. J. E.; Wychick. D. J. Poll Sci. 1976, 36. 2433 .

36. Ottaviani. M. F; Montalti. F.: Romanelli, M.: Turro. N. J.; Tomalia. D. A. J. Phus. Chem. 1996. 100. 11033

37. Ottaviani. M. F.: Montalti. F.: Turro. N. T.: Tomalia. D. A. l. Phus. Chem. B 1997. 101. 158

38. Baranski, A. S.: Fawcett, W. R.: Gilbert. C. M. Anal. Chem. 1985 57. 166 .

39. Baur. J. E.; Wightman. R. M. J. Electroanal Chent 1991, 305.73 